\title{
Historical Reflections on Infancy
}

\section{Alan Fogel}

Our daughter was the sweetest thing to fondle, to watch, and to hear. (Plutarch, Rome, second century, $\mathrm{BCE}$ )

What is best for babies? Cuddling and indulgence? Early training for independent selfcare? The answer depends upon the beliefs that people have about babies. Beliefs about infants and their care differ between cultures and they have changed dramatically over historical time within cultures. The contemporary technology of infant care in Western society, for example, first appears in the eighteenth and nineteenth centuries, with an increase in pediatric medical care, advice books for parents, parental devotion to the individuality of each child, books written especially for young children, and other infant care products and resources.

Why is it important to understand the historical origins and historical pathways of beliefs about infants and their care? Cultural history is vast in its domain, encompassing beliefs and values about human rights, morality, marriage and family, war and peace, love and death. Beliefs about infants are important because to raise a baby is to plant a seed in the garden of culture. We bring up babies in ways that are consistent with responsible childhood and adult citizenship.

Bronfenbrenner's (1979) Ecological Systems theory suggests how infants are embedded in networks of socio-cultural processes and institutions that have both direct and indirect impacts on infant development. Bronfenbrenner defined four levels of system functioning between persons:

The microsystem is made up of all the relationships between the person and his or her environment in a particular setting. For example, all of the transactions that take place between the child and the physical and social environment of the family or school form a microsystem.

The mesosystem includes the relationships between the major settings in which children are found. An example would be the interaction between the family and the day care 


\section{Fogel}

center. A child who is experiencing many difficulties in day care is likely to force the family to have more interactions with the center's teachers and administrators, and those family-school interactions should in turn have an effect on the child's functioning.

The exosystem extends the mesosystem to include other social systems that do not contain the developing child but have some effect on him or her. The world of work, neighborhood institutions, the media, the government, the economy, and transportation affect the functioning of the family, school, and other social settings in which children are found.

The macrosystem contains all of the various subsystems that we have been discussing. It contains all of the general tenets, beliefs, and values of the culture or subculture and is made up of the written and unwritten principles that regulate everyone's behavior. These principles - whether legal, economic, political, religious, or educational - endow individual life with meaning and value and control the nature and scope of the interactions between the various levels of the total social system.

Each of these systems has a history that is embedded within the larger history of a society. The "culture" of infancy, at any particular period in historical time, can be thought of as the complex set of relationships between and within each of these systems. In this chapter, I do not go into details about each of these levels of the system across historical time. Rather, the goal is a more general view of the macrochanges that have occurred across tens of thousands of years.

This chapter is based on research from secondary sources. These include the work of historians and anthropologists who have studied the primary sources of historical evidence, as well as translations into English of original historical documents. For prehistorical data, I rely on evidence from observers of modern hunter-gatherer societies as well as anthropological data. For the historical period, the focus will be on the work of historians and translators of original documents of Western culture (Judeo-Christian, Greek and Roman, and later European and American societies). This research approach may bias my interpretations in favor of the historian or translator who worked with the original documents and artifacts. A different point of view may arise from the work of a scholar who is competent to examine the evidence more directly.

This chapter highlights one major theme that was salient to me in collecting these materials, the historical continuity of a dialectic between empirical and romantic beliefs about infants. On the empirical side are beliefs related to the early education, training, and disciplining of infants to create desired adult characteristics and to control the exploration, shape, and uses of the body. Romantic beliefs favor the pleasures of babies and adults. Romantic ideas advocate indulgence in mutual love and physical affection in relationships, they show a respect for the body and its senses and desires, and the freedom of expression of all of the above. Although the terms empiricism and romanticism do not come into the English language until the eighteenth century, the earliest historical records reveal belief systems that will later come to be labeled as empirical or romantic.

The chapter is divided into the following sections: The prehistory of infancy (1.6 million to 10,000 years ago), early civilizations (8,000 $\mathrm{BCE}$ to $300 \mathrm{CE}$ ), the Middle Ages and Renaissance (third to sixteenth centuries), the Enlightenment (seventeenth to nineteenth centuries), and the recent past (twentieth century). The chapter concludes with a speculative section on the possible future of beliefs and practices about babies. 


\section{Prehistory of Infancy: 1.6 Million to 10,000 Years Ago}

It is currently thought that all humans are descended from a small population of huntergathers who first appeared in Africa during the Pleistocene epoch. The Pleistocene lasted between 1.6 million years ago and 10,000 years ago. Beginning about 10,000 years ago and continuing until the present time, humans gradually abandoned nomadic patterns and began to occupy permanent settlements and to develop agriculture. Homo sapiens hunter-gatherer societies first appeared about 100,000 years ago and were descended from a long line of other human species that arose at the beginning of the Pleistocene.

By about 35,000 years ago, homo sapiens sapiens hunter-gatherer groups existed in most locations in the old world, in Australia, and in the Americas. Societies of this period were composed of small bands of about 25 humans who sustained themselves by hunting game and gathering wild roots and plants to eat. They would roam typically less than 20 miles (30 kilometers) and it was rare to encounter another group. Generations lived their lives within this small sphere of people and place. Hunter-gatherer societies are believed to have been the only form of human society during the entire Pleistocene epoch. They did not leave artifacts or other documentation of their infant care practices (Wenke, 1990). Relatively few such societies survive today. While there is some controversy about whether surviving hunter-gatherers are similar to prehistorical hunter-gatherers, these contemporary groups are considered to be reasonable approximations to prehistorical lifestyles (Hrdy, 1999; Wenke, 1990).

The human ecology during the Pleistocene is considered to be the environment of evolutionary adaptedness, a term devised by John Bowlby the founder of attachment theory (Bowlby, 1969). This is the African Pleistocene environment in which the human adultinfant bond evolved for over a million years, an environment with large populations of predators who could easily kill and eat a baby. In order to protect the infant from this and other dangers, the infant was carried in a sling or pouch at all times, never left alone, and the caregiver responded immediately to fussiness in order not to attract the attention of predators. As a consequence, humans evolved a mother-infant relationship with continuous touch and skin-to-skin contact, immediate attention to infant signals, and frequent breast feeding (Barr, 1990).

The present day !Kung bushmen, a hunter-gatherer group living in the Kalahari desert in Africa, have been observed extensively. !Kung women carry their infants in a sling next to their bodies at all times. They breast feed on demand, as much as 60 times in a 24 hour period. The infant sets the pace and time of breast feeding.

Nursing often occurs simultaneously with active play with the free breast, languid extensionflexion movements in the arms and legs, mutual vocalization, face-to-face interaction (the breasts are quite long and flexible), and various forms of self-touching, including occasional masturbation. (Konner, 1982, p. 303)

Infants also receive considerable attention from siblings and other children who are at eye-level with the infant while in the sling. 


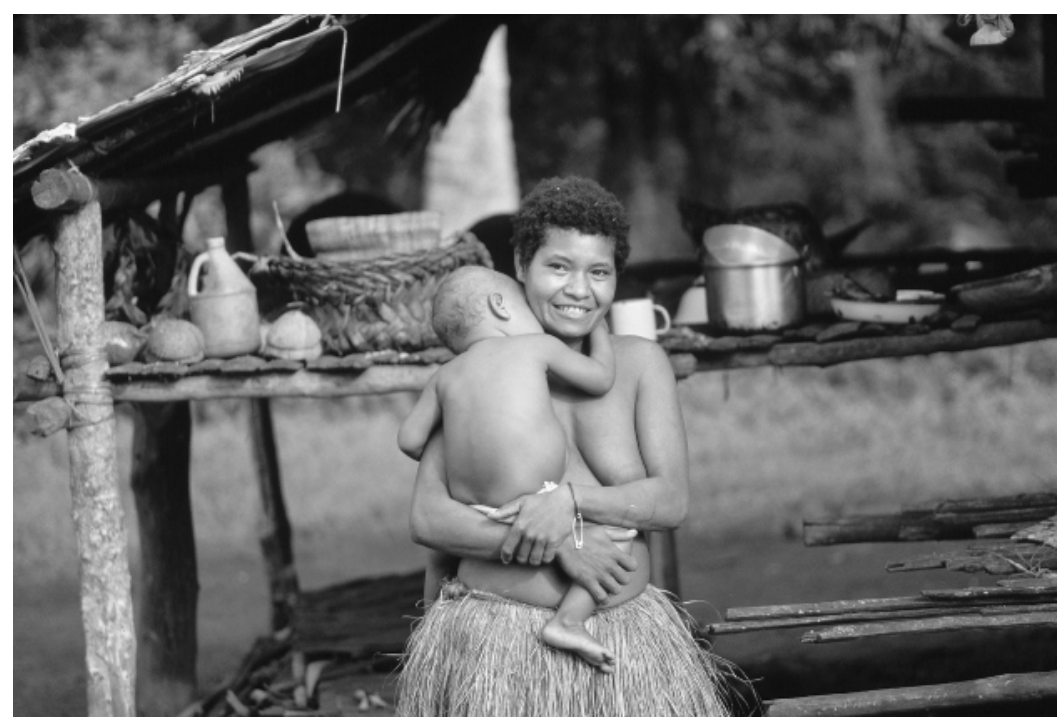

Figure 1.1 Infants in hunter-gatherer societies are in nearly constant skin-to-skin contact with people, as shown with this woman holding a baby in Huli village, Papua New Guinea. Source: Photo (C) Amos Nachoum/Corbis.

When not in the sling, infants are passed from hand to hand around a fire for similar interaction with one adult or child after another. They are kissed on their faces, bellies, genitals, are sung to, bounced, entertained, encouraged, and addressed at length in conversational tones long before they can understand words. (Konner, 1982, p. 302)

The high rate of nursing prevents infant crying and has a natural contraceptive effect to prevent the birth of another child while the younger one still requires mother's milk. Births are spaced every 4 or 5 years (Konner, 1982; Wenke, 1990). The present-day Elauma of Nigeria are also hunter-gatherers (Whiten \& Milner, 1986). Three-monthold Elauma infants spend almost all their time, whether awake or asleep, in physical contact with an adult or within three feet of the adult. Elauma mothers carry their babies with them while the mothers go about their daily chores (See Figure 1.1).

A similar account is offered from observations of the Fore people of New Guinea, a rain-forest hunter-gatherer group who remained isolated from the outside world until the 1960s. This group displays a "socio-sensual human organization [italics added] which began in infancy during a period of almost continuous, unusually rich tactile interaction" (Sorenson, 1979, p. 289). Play with infants includes "considerable caressing, kissing, and hugging" (p. 297).

Not only did this constant "language" of contact seem readily to facilitate the satisfaction of the infant's needs and desires but it also seemed to make the harsher devices of rule and regimen unnecessary. Infant frustration and "acting out," traits common in Western culture, were rarely seen. (Sorenson, 1979, p. 297) 
Because of this indulgence of the senses and a relative lack of overt discipline, huntergatherer societies exemplify a primarily romantic culture. Observations of weaning both in the !Kung and the Fore, however, suggest that the training of infants - empirical beliefs and practices - is also important. Although !Kung adults report memories of the difficulty of losing their close contact with their mother during weaning, they also report that these feelings were alleviated by the presence of other adults, siblings, and peers. Weaning occurs when the mother becomes pregnant with the next child. Adults believe that with the onset of pregnancy, the mother's milk will harm the nursing child and must be reserved for the unborn child. In the words of Nisa, a !Kung woman who spoke about her life,

When mother was pregnant with Kumsa, I was always crying, wasn't I? One day I said, "Mommy, won't you let me have just a little milk? Please, let me nurse." She cried, "Mother! My breasts are things of shit! Shit! Yes, the milk is like vomit and smells terrible. You can't drink it. If you do, you'll go 'Whaagh ... whaagh ...' and throw up." I said, 'No, I won't throw up, I'll just nurse.' But she refused and said, 'Tomorrow, Daddy will trap a springhare, just for you to eat.' When I heard that, my heart was happy again. (Shostak, 1983, p. 53)

Even here, in the most romantic of human lifestyles, in which the body and its senses are indulged and in which children receive very little discipline or restrictions, empirical beliefs are present in some form. The discourse between the romantic and the empirical may be a law of nature, derived from the simple truth that elders require of children some sacrifice if they are to grow into full coparticipation. If the sacrifice is done in the flow of a balanced dialogue, it will soon be followed by a new and surprising indulgence. The springhare helps Nisa to let go of her tragic loss and gives her a feeling of sharing in the more adult-like ritual of hunting. There is also evidence that hunter-gatherer groups occasionally used infanticide - the deliberate killing of unwanted infants and an extreme form of empiricist practice - for infants who were sick or deformed, those who could not have survived under the rigors of the harsh environment.

For most of human evolution, then, people lived close to the earth, either on open ground, in and near trees, in caves and other natural shelters. They were directly attuned to the earth, its climate, and its cycles. The basic elements of earth, air, fire, and water had enormous practical and spiritual significance. So far as we know, people did not distinguish themselves as separate from their ecology but as part of it, no different or more valuable than the basic elements, the plants, and animals (Shepard, 1998).

For people of the Pleistocene, the environment was not an objective collection of rocks and creatures; it was a form of consciousness in which there was an unquestioned and nonjudgmental sense of connection to all things. This has been called a partnership consciousness as opposed to the dominator consciousness that appeared later $(8,000-3,000 \mathrm{BCE})$ with the formation of towns, social hierarchies, power structures, and warfare (Eisler, 1987).

Beginning about 35,000 years ago, humans developed what has been called mythic culture, which saw the origins of symbols, representations, language, and storytelling that served as a way of making sense of the universe. Myths worldwide express the belief that the world, and all its creatures including humans, is sacred. In mythic culture, the universe cannot be changed or shaped. Myths served to integrate and explain the 
various facets of life and death that were accepted as they were and never questioned (Donald, 1991).

At this time, the first representational art and artifacts began to appear, in the form of cave and rock paintings and small figurines (Wenke, 1990). The paintings depicted animal and human forms, possibly spiritual or mythic figures. The figurines were typically about palm size and represented women with prominent breasts, hips, and vaginas. They were believed by many to represent fertility, while others suggest that they represented a goddess-type deity and a matriarchal social order (See Figure 1.2). These figurines may have conferred fertility on individuals and at the same time celebrated the mysterious life-giving power of the female.

It is probably during this phase of human prehistory that rituals marking the life transitions of birth and death, along with mythical interpretations of their meaning, first appeared. Although there is relatively little archeological evidence, we can learn a great deal about birthing rituals and practices from studies of living tribal societies. In many tribal societies today, for example, birth occurs in the company of women, close female relatives and older "medicine" women, shamans who are expert in the practice of childbirth. Plant and animal extracts are used for the pains of pregnancy and childbirth. In some matriarchal societies, husbands are asked to change their behavior when their wives are pregnant, a practice called couvade. Fathers in the Ifugao tribe of the Philippines are not permitted to cut wood during their wives' pregnancy (Whiting, 1974).

Healing practices and prayer rituals were created in prehistory to foster healthy fetal development and childbirth. One common practice, used by the Laotians, the Navaho of North America, and the Cuna of Panama, among others, is the use of music during labor. Among the Comanche and Tewa, North American Indian tribes, heat is applied to the abdomen. The Taureg of the Sahara believe that the laboring mother should walk up and down small hills to allow the infant to become properly placed to facilitate delivery. Taureg women of North Africa deliver their babies from a kneeling position (Mead $\&$ Newton, 1967). Many of these practices are ancient in origin, having been passed down between generations of women, perhaps from prehistorical times. The effectiveness of some of these practices is being rediscovered and applied by birthing centers and midwives in Western cultures today. The past 20 years has seen the emergence of professional doulas, women who are trained to provide advice, assistance, and emotional support to pregnant and laboring mothers.

Related to the belief system, in which all things in the universe are connected and have equal status, hunter-gatherers have an egalitarian social structure with respect to age and gender differences and have little political hierarchy. An instructive comparative study was done between a hunter-gatherer group (the Aka) and a neighboring agricultural group (the Ngandu) in Central Africa. Both groups live in nearly identical ecologies and have subsistence economies. The Ngandu are sedentary farmers with political hierarchies and inequalities in age and gender roles. The Ngandu use more infant care devices compared to the Aka. Infant care devices - such as cradles, carriers, and toys - are not needed in the Aka due to the constant contact between infants and adults. The Ngandu infants wear more clothing, are more often physically separated from their mothers, and mothers are more likely to let their infants fuss or cry compared to the Aka. Like mothers in the urban cultures, the Ngandu mothers use more objects when playing with their babies (Hewlett, Lamb, Shannon, Leyendecker, \& Scholmerich, 1998). 


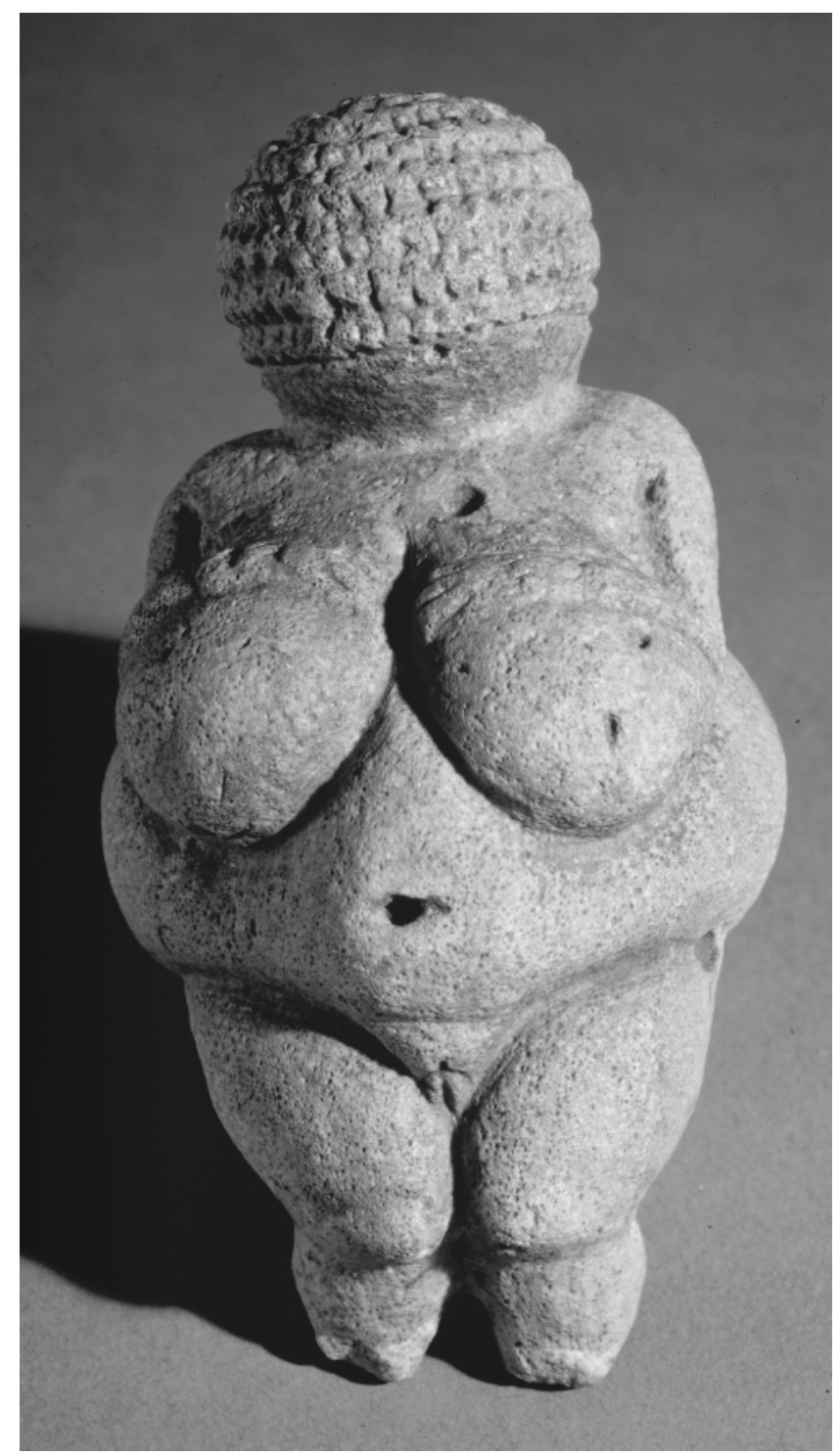

Figure 1.2 The Willendorf "Venus" (ca. 20,000 BCE) is one example of palm-sized statuettes that appeared to celebrate female fecundity. It is not clear whether these figures were used as talismans to promote fertility, as representations of a female goddess, or for some other purpose. Source: Photo AKG London/Erich Lessing.

The comparison between the Aka and the Ngandu suggests that there may have been a diversity of early human habits and belief systems related to infancy, even during the Pleistocene. While virtually all humans 100,000 years ago lived in desert and grassland environments, migration patterns eventually led to adaptations for living in less arid climates such as coastal and mountain terrain. In the desert, infants must nurse 
frequently to prevent dehydration, while this is not the case when the climate is more humid. Desert hunter-gatherers may have had to move frequently, requiring constant physical contact with the infant for safety. Coastal or riverbank hunter-gatherers may have had abundant resources close at hand, which would not have required extensive nomadic activity.

For these reasons, it is unwarranted to use the culture of desert-living hunter-gatherers as the sole basis for making inferences about species-normative patterns of the motherinfant relationship. The desert-living ancestral populations would have had mothers who cared for the infant full-time as well as working full-time. Infants from other huntergatherer cultures may not have needed such constant protection and nursing from the mother, allowing her to work while the infant was in substitute care (Hrdy, 1999).

In summary, infancy in prehistory was a very sensual and sensory experience. Infants developed an awareness of other human bodies from which they obtained nourishment, constant touch, affection, warmth, and support. They had the benefit of an extended family of group members. Once they began crawling and walking, infants became familiar with the feel and smell of raw earth and of plants. Living primarily outdoors and in earthen shelters, they became sensitized to changes in light and temperature, to the cycles and rhythms of the earth and its climate. To people living in urban societies today, this ancient way of life may seem primitive and dirty. On the other hand, it would be a primitive form of reasoning to reject the evidence of prehistory and what it has to tell us about human infants and their families.

For 1.6 million years, humans evolved to derive benefit from close touch and connection to other people's bodies, to the naked earth, to heat and cold, and to the smells, sounds, and tastes of the natural world. Humans of all ages perceived no distinctions between self and world, in the same way that young children today view others as extensions of themselves. They saw the world as animated with spirit and with the same kind of partnership consciousness as their own (Abram, 1996; Shepard, 1998).

The past 10,000 years, when humans moved into villages and later began to record their history in writing, is only $0.62 \%$ of human evolutionary history. If human evolution began at noon on an imaginary clock, villages and settled life would first appear at 4 minutes before midnight. Civilization, with urban centers, writing, and technologies, would arise about 2 minutes before midnight. The cradle of human consciousness is not a cradle at all. It is the belly of a parent, the loving hands of a brother or grandmother, the taste of milk rising from a teat, the smell of bodies, and a blanket of stars on a summer night. Every baby born today still has the opportunity to experience this "romantic" inheritance.

\section{Early Civilizations: 8,000 BCE-300 CE}

The Hebrew people left both archeological and written evidence about their childrearing practices (2000-500 BCE). The biblical Old Testament gives lengthy accounts of the family genealogy of the Hebrew peoples. Childbearing and childbirth were viewed as sacred acts, acts in which God was an active partner (Frymer-Kensky, 1995). When Eve, 
the mythical original mother, first saw her son Cain, she said, "I have created a man with God.” (Gen. 4:1).

There are many stories in the Old Testament about divine intervention in matters of fertility. Hannah, for example, prayed extensively and made vows to God to grant her the ability to conceive and give birth to Samuel. The Bible also gives detailed laws regarding women's behavior during menstruation, pregnancy, and childbirth. Although there are no direct descriptions of infancy in the Bible, it is clear from many of the stories that infants should receive loving care, appropriate blessings for a good and holy life, and that male infants should be circumcised. Parental devotion was also evident in stories about the suffering of parents who were asked to sacrifice their infants. When two mothers claimed to be the parent of the same child, Solomon's threat to kill the child revealed the true mother, whose pain was unmistakable. The Hebrew slave revolt in Egypt, which led to the Exodus and return to the promised land, was precipitated by a Pharonic edict to kill Hebrew first-born sons. The story of Moses, sent floating down the Nile by his heartbroken family and adopted into love by Egyptian royal women, places the concept of human freedom in direct metaphorical alignment with the act of saving a single infant from death (Frymer-Kensky, 1995).

The Bible reminds parents not only to love but to educate their children, a combination of romantic and empiricist views. The importance of teaching children about culture was written in commandments to Abraham to "instruct" his children (Gen. 18:19). Regarding the important facets of Hebrew culture, parents were asked to "teach them intently to your children ... when you sit in your home" (Deut. 6:7). Childrearing among the ancient Hebrews involved discipline accompanied by respect for the child, as the following passages illustrate: "Train a child in his own way, and even when he is old, he will not depart from it" (Prov. 22:6); "Foolishness is bound in the heart of the child but the rod of correction shall drive it from him" (Prov. 22:15); and "Chasten your son for there is hope, but set not your heart on his destruction" (Prov. 19:18). While some have interpreted these statements as grounds for justifying corporal punishment, the Old Testament does not specify the type of punishment but makes clear the need for discipline in the context of love. Other Bible stories reveal the undesirable outcomes when discipline is too harsh or nonexistent or when parents fail to educate their children into the stories, rituals, ideals, and history of the culture.

The ancient Egyptians (3000-1000 вСЕ), while not averse to killing Hebrew babies, expected Egyptian parents to have a large number of children. Parents were expected to take pleasure and pride in their children and to provide love and care. Tomb paintings for the pharaoh Akhenaten and his wife Nefertiti (1378-1362 вСЕ) show them holding their children on their laps, kissing them, and giving them affectionate hugs. Infants were breast fed until about 3 years of age. Infants and children during this period were constantly in the presence of caring adults, both parents and substitute caregivers, and the whole family spent "quality" time together on walks or picnics. Complex toys from that era have been found in archeological sites including dolls with moving limbs, animal pull toys with moving parts, and puppets. Physicians treated and wrote about common childhood diseases, which were of great concern to parents (French, 2001).

History and literature from ancient Greece and Rome (500 вCE -300 CE) also reveal a mixture of romantic and empiricist sentiments towards infants. The Greeks clearly 
believed that infants and children were naturally unruly and difficult to control, and therefore needing discipline and guidance. Writers advocated a strict upbringing for the purpose of creating a worthy citizen. Babies were thought to be soft and formless at birth and consequently needed to be hardened and molded. Various devices were used to keep infants' hands open, their legs held straight, and their arms strapped against the body. The right hand was loosened at 2 months to ensure that the child grew up right handed. Swaddling bands were used to mold the infant's head and body shape. Infants were bathed in cold water to prevent them from remaining too soft. Nurses used bath times to further mold the child's skull into a round shape, while attempting to shape other body parts by pulling and stretching (Dupont, 1989). The binding and manipulating of infants was not uncommon in ancient times, as seen in the foot binding of girls in ancient China (which made their feet small but deformed) and head binding in the ancient Maya (Mexico). Head binding of infants can also be found in eighteenth century Europe to give the head an oblong shape (Johnson, 1992).

Roman parents viewed these practices as an expression of their love, so children would grow up strong, their bodies well proportioned and held in appropriate postures. The recognition of the importance of the body for the developing person is salient in Greco-Roman heritage. Exercises for the body were thought to contribute to a strong moral character, a belief that was revived in the eighteenth and nineteenth centuries, following centuries of Christian doctrine that deemphasized the pleasures of the body. People from the educated classes in the Greek and Roman world were expected to hold their bodies in postures appropriate for each occasion and to speak in a dignified way. Gestures were stylized and specific to gender. The nude body was celebrated in real life - clothing was scant and sheer for both gender - and in nude sculptures of both males and females.

Parental devotion to children, especially among the wealthy, is well documented in Roman literature. Fathers and mothers were equally involved in the care of infants. One of the most detailed descriptions of parental love comes from Plutarch in the second century BCE, Plutarch shared childcare with his wife for all their children. They had one daughter, Timoxena, who died when she was 2 years old (French, 2001). Since Plutarch was away at the time of his daughter's death, he wrote these words in a letter to his wife.

There is a special savor in our affection for children of that age; it likes the purity of the pleasure they give, the freedom from any crossness or complaint. She herself too had great natural goodness and gentleness of temper: her response to affection and her generosity both gave pleasure and enabled us to perceive the human kindness in her nature ... our daughter was the sweetest thing to fondle, to watch, and to hear; and we ought to let the thought of her also dwell in our minds and lives, for there is much more joy in it than sorrow. (Pomeroy, 1999, pp. 59-60)

Although infants were denied affection, older children whose character had begun to form were lavished with hugging and kissing (Dupont, 1989; Gies \& Gies, 1987). Toys and 
games for young children and the values of love and protection for them have been found in artifacts and documents from ancient Egypt (2,000-100 вСЕ) and Greece (800-200 вСE) (Greenleaf, 1978).

As in the Hebrew culture of the Middle East, Greeks and Romans invoked their own deities for assistance in supporting the baby's health and growth. Prayers and offerings were made for successful childbirth and at each stage of the infant's life. The belief that infants' birth and development was a collaboration with gods or goddesses seems to follow from the partnership consciousness of the Pleistocene. Infants in these ancient cultures were not seen as belonging to the parents or as brought into the world by human choice. Rather, they were seen as part of a divine plan, as one manifestation of the way the universe works either to the favor or disfavor of humans.

Following prehistorical societies, many early civilizations, such as ancient Rome, practiced infanticide. The male head of a Roman family had the duty to decide if a newborn should live or die. This practice eliminated infants who were malformed or sickly. Malformation was thought to be due to an animal nature. Many healthy babies were also left to die because the family was too poor or the child unwanted (Dupont, 1989). Infanticide continued in Europe throughout the Middle Ages, until Christian beliefs diminished the regular use of the practice.

Hebrews did not routinely use infanticide. The story of Moses and the Exodus from Egypt shows that the concept of killing infants was appalling to the Hebrews. Since the Middle Ages, the narrow passage through the Red Sea and to eventual freedom is a central metaphor in Jewish prayers for successful childbirth through the birth canal (FrymerKensky, 1995). These ancient Hebrew ideas about the sanctity of childbirth and the creation of new life were later incorporated into Christian beliefs.

In summary, we can never know about the details and diversity of actual infant-care practices during ancient historical times. Documents written by educated leaders may contain more prescriptive and idealistic visions of parenting, visions that the ordinary family may or may not have put into practice. It seems clear, however, that both romantic and empirical beliefs about infants can be found in the earliest written documents of Western Cultures. Roman writings tended to weigh the empirical side more heavily while the Hebrews showed more of a balance between love and discipline. Following the traditions of mythic culture, these ancient historical societies believed that infants were conceived in partnership with a deity that was beyond themselves. Education was required in order to create an adult who was best attuned to the will of the gods or goddesses who were responsible for the mythical foundations of the cultural practices: to cultivate the body and its senses in order to be in more touch with divinity in the human and nonhuman world.

\section{Middle Ages and Renaissance: Third Century to Sixteenth Century}

The early Middle Ages in Europe (300-1100 CE), began with the fall of the Roman Empire and the gradual spread of Christianity. Primarily rural populations began to settle 
in cities and towns. Political boundaries changed during a series of conflicts for power and control over territory. These factors contributed to the growth of an educated urban population living next to a class of urban poor who subsisted in more unhealthy conditions than the poor living in the countryside. As a result of disease, malnutrition, urban pollution, and ignorance, infants of the urban poor were more likely to die or to suffer birth defects than those from rural areas. As disease claimed the lives of both infants and of mothers in childbirth, many destitute or orphaned children walked the streets as beggars, thieves, and prostitutes. The prognosis for children growing up in urban poverty is not much different today.

After $400 \mathrm{CE}$, the Christian church began having an impact on the beliefs and practices of European childrearing. Christians, following ancient and contemporary Jewish practices, advocated parental love and worked to protect children from infanticide, abortion, and maltreatment. Gravestones for infants began to appear at this time, as well as special penances if a parent had done some wrong to a child (Gies \& Gies, 1987).

One of the first written accounts that focuses specifically on infant development and infant care beliefs can be found in the Confessions of St. Augustine (354-430 CE). Augustine was from North Africa. He studied in Rome and Milan and later became a priest in Alexandria. His autobiographical account in the Confessions (1991) begins with a remarkably detailed and developmentally appropriate reporting of his own infancy. He describes his birth and goes on at length about how he sucked from the breast and his patterns of quieting and crying. He reports that his first smiles occurred during sleep, which can be observed in infants today.

Augustine considers it important to establish the source of his data in the following way. "This at least is what I was told, and I believed it since that is what we see other infants doing. I do not actually remember what I then did." And he goes on, "Little by little, I began to be aware where I was and wanted to manifest my wishes to those who could fulfill them as I could not. For my desires were internal; adults were external to me and had no means of entering into my soul" (Augustine, 1991, p. 8).

Augustine struggled, as he did throughout the Confessions, with the moral implications of his "childish" acts. Many of these infantile actions, especially those regarding the pleasures of the body, would have been immoral from his adult Christian perspective. He concluded that what would be wrong for an adult was natural for babies. Since babies could not voluntarily control their behavior, he decided that they were expressing God's will and should therefore be tolerated for the indiscretions of their youth. "Was it wrong that in tears I greedily opened my mouth wide to suck the breasts?" (Augustine, 1991 , p. 9). These writings express one of the clearest and earliest statements in the romantic tradition, that the natural tendencies of infants are to be accepted, tolerated, and loved.

Evidence of romantic views and Christian love for infants can be seen in the writings of Gregory of Tours (sixth century), who describes an epidemic of dysentery that killed many infants: "and so we lost our little ones, who were so dear to us and sweet, whom we had cherished in our bosoms and dandled in our arms, whom we had fed and nurtured with such loving care" (Gies \& Gies, p. 60). Around the same time, the church developed forms of penance for killing infants: 3 years for abortion and 10 years for infanticide. Other writers of the time report parental mourning of infant death. 
We know a great deal about the emotional life of people in the Middle Ages. Events such as the death of an infant would have been marked by deep mourning, benedictions, and ceremonies. One historian of the Middle Ages describes everyday life this way:

All experience had yet to the minds of men the directness and absoluteness of the pleasure and pain of child-life ... Calamities and indigence were more afflicting than at present; it was more difficult to guard against them, and to find solace. Illness and health presented more striking contrast; the cold and darkness of winter were more real evils ... All things presenting themselves to the mind in violent contrasts and impressive forms, lent a tone of excitement and of passion to everyday life and tended to produce that perpetual oscillation between despair and distracted joy, between cruelty and pious tenderness which characterize life in the Middle Ages. (Huizinga, 1954, pp. 9-10)

We can infer from Christian art and theology that these heightened emotions occurred at times of both birth and death. In the early Middle Ages, representations of Christ depicted him as an adult engaged in acts of kindness and love. By the late Middle Ages (1100-1300 CE), images of Christ either focused on his death and the deep mourning of his companions, or on his infancy and the joy of the mother-child bond. The paintings of the infant Christ held by Mary continued to evolve during this period. When Christ first appears in paintings as an infant, the posture and body proportions are more adultlike. By the later Middle Ages, Christ looks more like an actual infant. The infant Christ is typically shown in stylized clothing and with adult-like facial features and mannerisms (See Figure 1.3). One painting depicted Christ as an infant making the Catholic gesture of benediction to a group of people kneeling before him. In Renaissance art (after 1400 $\mathrm{CE}$ ), by contrast, infants and children began to look and behave differently from adults. Children were sometimes shown playing with toys (Koops, 1996). Not only does the infant Christ begin to look more like a real baby (see Figure 1.4) but we also see the emergence of secular paintings of everyday family life and portraits of individual children.

Also appearing in the later Middle Ages were several medical texts giving advice for childbirth and early infant care. Trotola, a female physician in twelfth-century Italy, advised rubbing the newborn's palate with honey, protecting it from bright lights and loud noises, and stimulating the newborn's senses with cloths of various colors and textures, and with "songs and gentle voices" (Gies \& Gies, 1987). In England during the same period, birth often occurred in a warm chamber with plenty of bath water, accompanied by the scent of olives, herbs, and roses. It was attended by a female midwife and female friends bringing good fortune and joy (Hanawalt, 1993). During the Middle Ages as in ancient times, the body was viewed as part of God, the earth, the family, and the community. Birth took place in public, attended by female relatives, neighbors, and midwives.

In both Jewish and Christian beliefs of this time, the mother and infant's shared embodied experience were as sacred and important as that shared between husband and wife in the act of love and conception. The great romantic tales of the Middle Ages created the concept of courtship, honor, love, and sacrifice in couple relationships. Trotola's prescriptions for birth - with colorful textiles and captivating aromas - would 


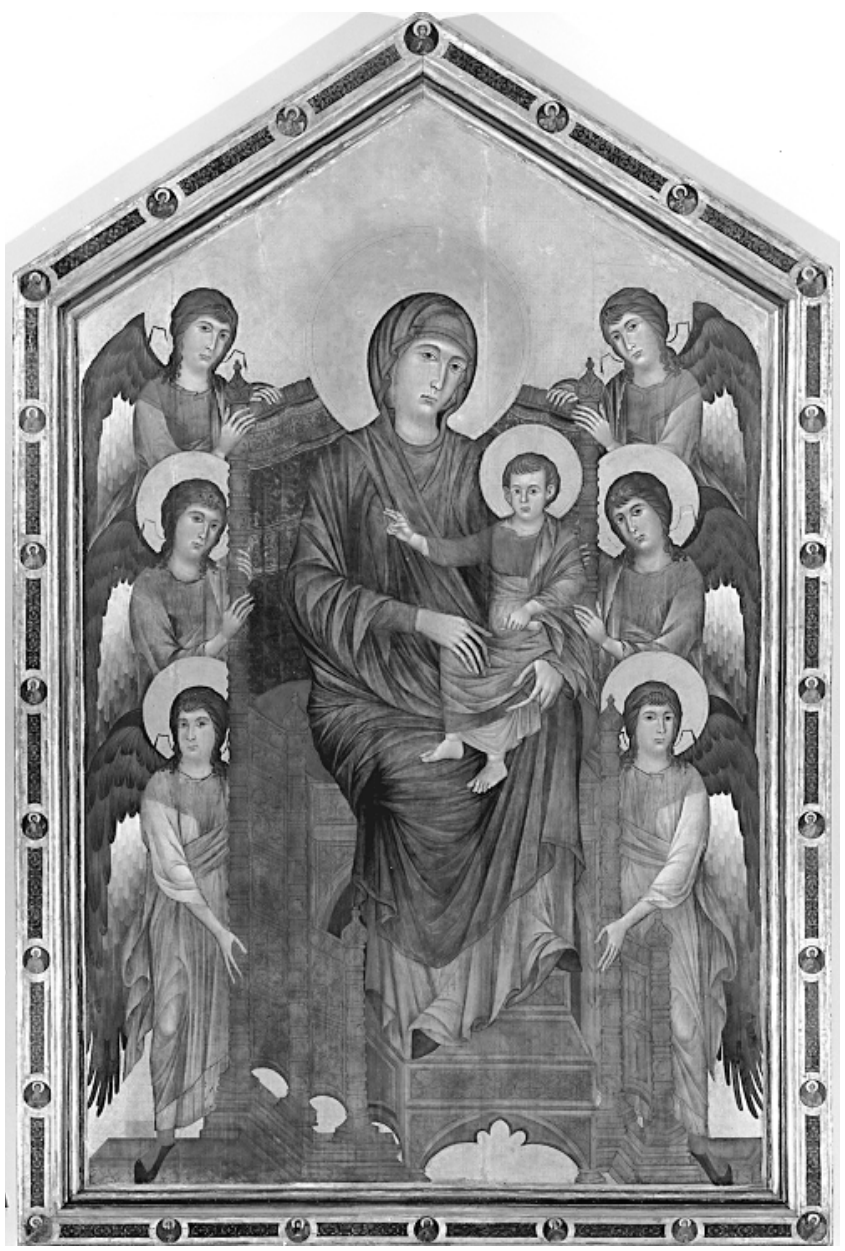

Figure 1.3 Cimabue, Madonna of the Angels, 1270. In this late medieval painting, Christ is represented in stylized form with adult-like gestures. Source: Louvre, Paris/Photo Hervé Lewandowski, RMN.

also have been found on the bodies and in the bedrooms of courting and newly married couples. The romantic view of love and the sacred body did not extend to other sexual or pleasurable acts outside of those reserved human relationships that were deemed by Christians and Jews to be part of the expression of God's love. Christian baptisms - like weddings - were a public ritual welcoming, taking place in the church where ancestors were buried. The biography of Bishop Hugh of Lincoln (1140-1200) describes details of infant action during one baptism led by the Bishop. The infant "bent and stretched out its little arms, as if it were trying to fly, and moved its head to and fro. The tiny mouth and face relaxed in continuous chuckles" (Gies \& Gies, 1987, p. 203). Apparently, Bishop Hugh took great pleasure in the baby, who was wrapped in the spiritual significance of the ceremony. 


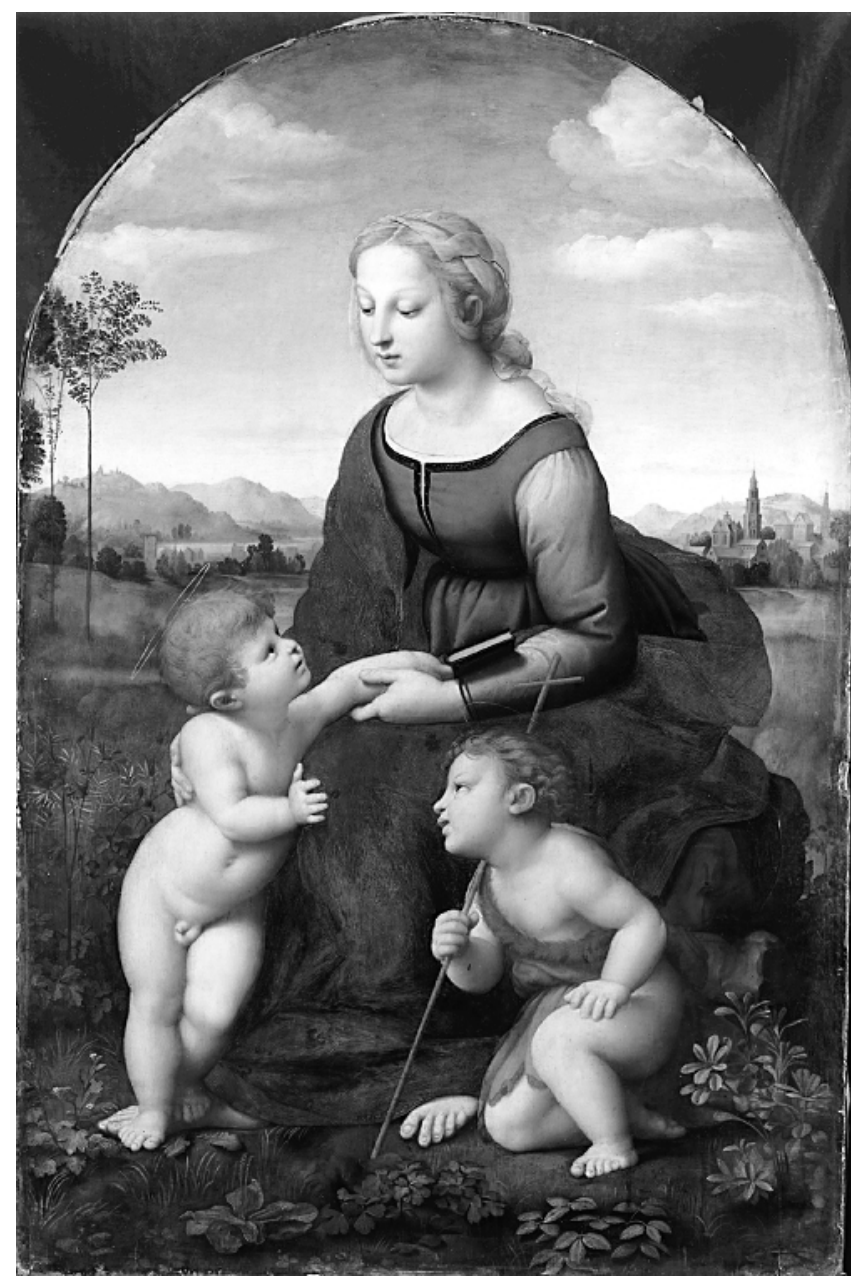

Figure 1.4 Raphael, The Virgin and Child with St. John the Baptist, 1507. By the time of the Renaissance, Christ was depicted more like a real baby, with an appearance distinctly different from adults. Around this time, secular paintings of children began to appear, showing an increasing interest in the individual. Source: Louvre, Paris/Photo J. G. Berizzi, RMN.

Following the ancient Roman empiricist traditions, infants in the Middle Ages were seen by upper-class families as pliable and soft, needing swaddling and straightening. Wet-nurses began to be used extensively for the wealthy. A wet-nurse was a woman who was paid to nurse the child with her own milk in order to spare wealthy women from the task of nursing the baby themselves. Selection of wet-nurses was important because they were believed to transmit character to the child. Writers, mostly from the church, condemned the practice of giving children to wet nurses from the poorer classes because of the belief that the child could pick up the habits and diseases of the nurse. The Renaissance artist, Michelangelo, half-jokingly claimed that his skill in sculpture was derived from his wet-nurse, the wife of a stonecutter (Gies \& Gies, 1987). 
Infanticide, however, was still practiced in the late Middle Ages. Although parents had to suffer penances, it was not a crime equivalent to homicide as it is today. By the thirteenth century, some cities in Europe created church-run hospices to adopt orphaned children as an alternative to infanticide, since a child who died unbaptized was barred from heaven for all eternity (Le Goff, 1987). In some countries today, with urban stress and poverty, infants are left in parks and in trash bins. Some cities in the United States and Northern Europe have begun programs that allow mothers to drop unwanted infants at local hospitals without prosecution. Social service agencies then help to find foster homes for these children. Times may have changed but some of the problems still remain.

The European Renaissance (1450-1650) began in Florence, Italy where wealthy patrons funded the development of art and science on a scale not seen since ancient times. This flowering of culture gave rise to the emergence of a philosophy of humanism. Paintings of nude figures, of secular themes, and of ordinary people rather than religious figures heralded a reawakening of the values of empiricism and romanticism that were part of classical traditions. As a consequence, the rearing of children took on more importance.

Responsibility for oneself and for one's children was shifted toward the individual. God was still present but people were beginning to feel empowered to make more decisions for themselves and their children. At this time, we begin to see the emergence of written philosophies of childrearing in Western cultures. One example comes from Michel de Montaigne (1533-1592), of France. He condemned violence in education, favored training for honor and freedom, and condemned wet-nursing.

A true and well-regulated affection should be born and then increase, as children enable us to get to know them; if they show they deserve it, we should cherish them with a truly fatherly love ... we feel ourselves more moved by the skippings and jumpings of babyish tricks of our children than by their activities when they are fully formed, as though we loved them not as human beings but only as playthings. Since in sober truth things are so ordered that children can only have their being and live their lives at the expense of our being and of our lives, we ought not to undertake to be fathers if that frightens us. (Screech, 1991, p. 435)

As a result of the spread of Renaissance humanism throughout Europe, by the eighteenth century, a profound shift in Western cultural consciousness coalesced, one that emphasized the importance of individuals in their own right. Up through the seventeenth century, the ancient belief persists that all people, including infants, are part of a larger cosmos of God in partnership with the family. Before the eighteenth century, children were typically given the names of family members, often that of an older sibling who had died, in order to emphasize the historical and sacred connection of one person to another. One sign of the shift toward individuality in the early eighteenth century is that children begin to be given unique names showing their special status as human beings (Stone, 1979). This focus on individuality led gradually to the emergence of private homes, arguments for the freedom of children and of people of all ages, and separate rooms in the house for children. At the same time, we begin to see an increasing distance from nature and from a direct connection with the earth and with God (Gelis, 1989). 
In summary, this period in Western culture had two phases. The first was a gradual change in classical ideas about the importance of the body and its senses. Christian empirical beliefs favored innocence, chastity, and denial of the senses as a pathway to God. In contrast, the classical empirical traditions acted to the favor of the gods by shaping the body into a form to be enjoyed and displayed. Augustine could forgive the infant's hungers only until a proper Christian education could begin. This showed that Christians were more romantic in their views about infancy than the Romans, for example, who advocated relatively early and severe discipline of the mind and body.

The second phase of the period from the thirteenth century to the sixteenth century is the emergence of humanism during the Renaissance. This period is a reprise of the classical themes about the body and its senses set against the historical background of 800 years of Christian domination of Western culture. These struggles, begun in the palaces of the most wealthy secular and religious leaders, led eventually to a broader cultural shift in the importance of the individual as distinct from God, family, and society.

\section{The Enlightenment: Seventeenth Century to Nineteenth Century}

During the eighteenth century, new ideas about the value of human life, dignity, and freedom began to emerge, a shift of cultural consciousness that is called the "enlightenment." On the one hand, there is a revival of classical romantic beliefs as exemplified in the writings of Jean-Jacques Rousseau (1712-1778). Rousseau, who lived shortly before the period of the French revolution against the monarchy and was a major influence on it, argued that childhood was a time of special privilege, that children bring goodness into the world, and that education should be sensitive to the needs and inclinations of the infant and young child. Rousseau initiated a social movement that, for the first time, acquires the name romanticism. Many of Rousseau's ideas, however, had their origins during earlier historical periods. What is new here is the emphasis on the romantic individual, the importance of the child as a person in his or her own right.

Included in this movement are the great English romantic poets, such as William Wordsworth (1770-1850), who wrote of childhood in a way that would have been recognized by members of a hunter-gatherer community.

Behold the Child among his new-born blisses,

A six years' darling of pygmy size!

See, where 'mid work of his own hand he lies,

Fretted by sallies of his mother's kisses,

With light upon him from his father's eyes!

(From "Intimations of Immortality from Recollections of Early Childhood," in Williams, 1952, p. 263)

Other authors, such as William Blake (1757-1827) and Charles Dickens (1812-1870), also wrote about the life and fate of individual children but they had a less than romantic view about them. In Oliver Twist and other famous stories, Dickens courageously exposed the effects of disease, poverty, child abuse, and child labor for all to see. Thus, while the 
value of the individual was on the rise, people disagreed about what was "natural" compared to what needed to be provided for the child's healthy development. John Locke (1632-1704) believed that children needed more guidance and discipline than the romantics advocated. Locke argued that education should provide the skills to make rational choices. The philosophical movement to which he belonged was for the first time given the name empiricism. The origins of Locke's ideas can be found in ancient sources such as the Old and New Testaments and Roman ideas about education. He echoed the contemporary cultural ideals about the importance of the individual. He wrote, "the little and almost insensible expressions on our tender infancies have very important and longlasting consequences" (as quoted in Clarke-Stewart, 1998, p. 104).

Reversing centuries of Christian doctrine that elevated the spirit above the body, Rousseau and Locke revived the ancient Greek and Roman ideals about the importance of the body in healthy moral development. Locke gave us the now well-known expression, "A sound mind in a sound body, is a short but full description of a happy state in this world." Rousseau suggested that children should "run, jump and shout to their heart's content." Swaddling was abandoned during the eighteenth century because Locke complained that it restricted the infant's freedom of movement and prevented the mother or wet-nurse from hugging and caressing the baby. Parents were advised that infants should exercise early and use their legs. Within a few years, swaddling was being condemned in England as an assault on human liberty.

The eighteenth century, and its rising concern for the individual, also saw a proliferation of advice books for parents. Between 1750 and 1814, 2,400 different childrearing advice books were published. By 1800, an entirely new concept entered society: books published exclusively for young children. A large range of inexpensive children's books appeared as quickly as the spread of computer games in the late-twentieth century. Around the same time there was an increase in the number of family portraits for the middle and upper classes. The invention of photography and film during the nineteenth century, and digital recording media after another century, continued to expand this tendency to document individual and family lives. The introduction of the Kodak Brownie camera in the early part of the twentieth century brought family documentation even to the poor. The Brownie was easy to use, inexpensive, and users did not have to develop the film themselves.

The rise of the importance of the individual corresponded with an increase in the importance of the nuclear family. There was a shift away from the use of wet-nurses and a move toward the maintenance of a private family home. These two changes had the effect of lessening the duration of breast feeding. Prior to the eighteenth century, infants were breast fed to at least 18 months. Because the value of the individual applied not only to infants but to their mothers and fathers, a conflict began to appear between the rights of parents and the rights of infants. Mothers wanted their own personal time and began to see breast feeding as their responsibility and their burden. The result was that infants were weaned earlier. Husbands wanted their wives to remain sexually available and attractive and became jealous of the infant's monopoly of the breast, which was a factor contributing to the relative increase in the importance of the conjugal bond in relation to the mother-child bond. These historical changes in the family were not seen in all cultures but became the norm for Western families. 
During the nineteenth century, the child became an integral part of the definition of the family. What has been called the "discovery" of the child was due to a number of historical currents that flowed through urban Europe and North America. The first current was the segregation of the family from the workplace and the decline of child labor (thanks in part to Dickens). Second, society began to define the mother's role as major supervisor of the home. It may surprise many people that the full-time mother and housewife is a relatively recent historical invention. The final current established love or sentiment (rather than religion, family inheritance, or economic well-being) as the bond holding the family together (Hareven, 1985). This latter current was also coupled with a rise in the significance of the love bond between spouses. As a result, parents became more loving, permissive, and egalitarian with infants and children (Clarke-Stewart, 1998).

The development of this segregated nuclear family and its full-time mother was at first confined to the white middle class. Families from other classes and ethnic and racial groups continued to live in extended families in which love, work, and education all took place within the home and childcare was shared by all family members. Women in these families continued to work in the fields and in the home in the company of their babies, a practice that had been going on for most of human history (Hareven, 1985).

Welfare and medical institutions devoted exclusively to infants and children did not appear in Europe and North America until the 1850s. Around the same time, we see the development of immunization against childhood diseases and the pasteurization of milk. Maternal deaths during childbirth also declined due to the invention of anesthesia and procedures for sterilizing medical instruments (Greenleaf, 1978). These medical advances further solidified the family by reducing infant mortality. On the other hand, they led to a growing trend to move childbirth out of the home and the company of female friends and relatives and into hospitals surrounded by unfamiliar medical (mostly male) and nursing staff.

Empiricist views could be seen in the rise of education for infancy. Infant schools in the nineteenth century were meant for poor children, for early prevention of childhood disorders, for combating urban crime, teaching reading, or to give poor children proper middle-class values and supports (Clarke-Stewart, 1998). Infant schools later became available to middle-class families. In 1840, in Massachusetts, half of all 3-year-olds were enrolled in infant schools. Later in the nineteenth century, however, the practice of sending infants to school was condemned because it put too much pressure on children. The romantic view reemerged in the belief that children should develop naturally instead of being "pushed." Similar ebbs and flows of the value of infant education (schools, musical training, reading, etc.) can be seen throughout the twentieth century.

The nineteenth century was also a period in which science became a new voice of authority, gradually supplanting religion as the sole source of knowledge and guidance. Observations of infants were first recorded by educated European and North American parents during the eighteenth and nineteenth centuries. Their diaries, known as "baby biographies," were partly meant to document the individual child and his or her development and partly meant as observations in the scientific tradition of natural history. One has to put the baby biographies into historical context to understand their significance. Never before had people devoted time and energy to the documentation of the life of a single, individual baby. 


\section{Fogel}

Biographers were aware of the distinction between a more empirical approach and a more romantic approach to their recordings. Charles Darwin, for example, recorded the development of his son, William. When William was only a few months old, Darwin was trying to be an objective observer. He added more references to himself as his affections for William grew and as William became more expressive. He thought these references to himself were unscientific, so they were deleted in the versions of his diary that he published (Conrad, 1998). Darwin, like Plutarch, wrote a eulogy for his daughter, Annie, who died at age 10, in which he revealed - more so than in any of his other writings - a romantic side. As if echoing the words of Plutarch almost 2,000 years earlier, he wrote of Annie that she lived "as if she defied the world in her joyousness" (Conrad, 2004).

Female diarists were more generally romantic. Elizabeth Gaskell (1810-1865), a wellknown English novelist of the time, wrote a brief biography of her oldest daughter, Marianne, the first of her seven children. Gaskell focuses mostly on moral development in comparison to the male diarists who recorded primarily sensori-motor and expressive development (Wallace, Franklin, \& Keegan, 1994). She recognized her stance as participant observer in the following passage describing Marianne at 6 months.

I should call her remarkably good-tempered; though at times she gives way to little bursts of passion or perhaps impatience ... she is also very firm ... what I suppose is obstinacy really, only that is so hard a word to apply to one so dear. But in general she is so good that I feel as if I could hardly be sufficiently thankful, that the materials put into my hands are so excellent and beautiful. And yet it seems to increase the responsibility. If I should misguide from carelessness or negligence! (Gaskell, 1996, p. 5)

This passage is enlightening because it gives us a view of the infant-mother relationship and not just of the infant. Diaries were later dismissed by more empirical (i.e. less romantic) scientists in the twentieth century, in part because they could not be verified as scientifically objective.

In summary, the most radical historical change in beliefs about infancy began to unfold during the period between the seventeenth and nineteenth centuries. The rise in the importance of the individual had its roots in earlier Judeo-Christian beliefs about the value of human life and the importance of cultural education. The Renaissance saw a decline in religious art and the emergence of secular themes, texts, and paintings about ordinary people rather than religious or mythical figures. Although these historical roots are unmistakable, the rapid advances in technology, in science, and in education during the Enlightenment created the conditions for a major historical change in cultural consciousness - the emergence of the "individual" - a change that affects every aspect of life in Western societies today. The codification and consolidation of human rights, liberties, and self-enhancement was propelled by people who had unique names, whose identity was founded upon personal accomplishments, and who grew up in a family that respected them as growing individuals (See Figure 1.5). Baby biographies, and the belief in the importance of individual infants, opened a path into a historically unprecedented documentation of infancy during the twentieth century. 


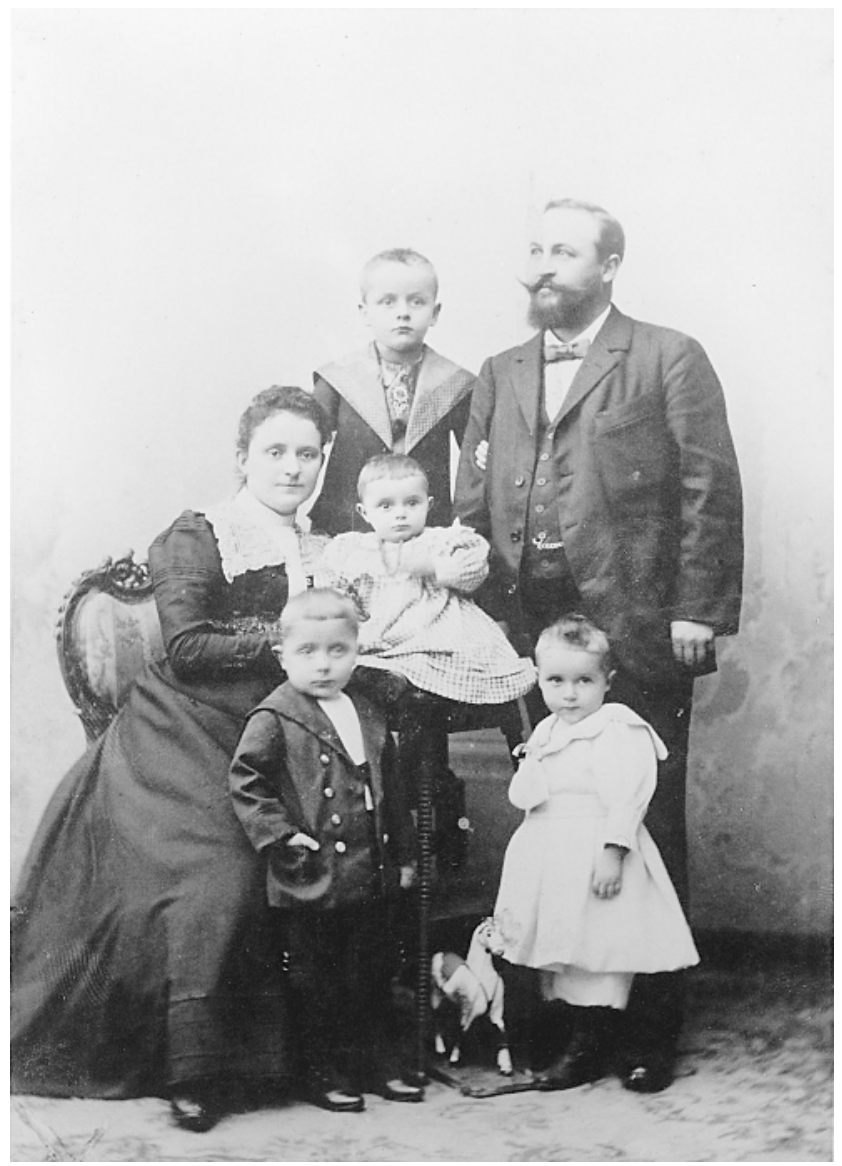

Figure 1.5 During the nineteenth century, infants and children became accepted as unique individuals. They received given names that were different from names of other family members, had the benefit of pediatric care, and the opportunity for educational enrichment. Note how this Berlin family (ca. 1896) dressed each of their children, including the infant, with unique and well-tailored clothing. Source: Photo AKG London.

\section{The Recent Past: Twentieth Century}

Changes in beliefs about infancy seem to have accelerated during the twentieth century, in part because of mass communication about infancy and infant care and because of an increase in scientific studies of infancy. The history of infancy during the twentieth century is characterized by continual debates between romantic and empirical sentiments, as well as shifts every 5 to 10 years between infant care practices favoring one view or the other. It also becomes increasingly difficult to separate the history of infancy research 


\section{Fogel}

from the history of infants in the family. Infancy research has impacted every facet of infant care. At the same time, scientists as people living during these times were impacted in their own life histories with the beliefs of the larger culture and those beliefs permeated the methods and values of their science.

Earlier debates over romanticism versus empiricism were replaced in part by discussions about the contributions to development of nature (genes) versus nurture (environments). Arnold Lucius Gesell (1880-1961), the founder of "nativism," following in the romantic tradition, claimed that the orderly changes seen in early development were specified by the genes; developmental stages were "natural." Gesell, who made careful measurements of developmental changes in size, motor skill, and behavior in infants and young children, was the first scientist to use a one-way mirror for unobtrusive observation and the first to use film to record behavior. John B. Watson (1878-1958), an empiricist in contrast to Gesell, believed that, given the right kind of "nurture," infants were entirely malleable. He taught small children to be afraid of cuddly animals by making loud noises whenever they touched the animals, research that would be considered unethical today. Watson was successful, however, in convincing people that even the most basic and innocent of infant behaviors could be shaped by outside forces.

Watson's childrearing advice harkened back to the ancient Romans. Parents were told not to hug and kiss their children, except on the forehead before going to bed, or a pat on the head if they performed well on a task. Mother love was a "dangerous instrument. An instrument which may inflict a never healing wound, a wound which may make infancy unhappy, adolescence a nightmare, an instrument which may wreck your adult son or daughter's vocational future and their chances for marital happiness" (Watson, 1928, The psychological care of the infant and child, as quoted in Konner, 1982, p. 311). Watson was especially appealing to immigrants coming to North America, people who believed that they could make a new life for themselves and their children. Anyone could succeed, regardless of past history or genetic heritage.

Given the ancient historical dialectic between empirical and romantic beliefs, Watson's extremism was begging for a romantic counter-argument. It appeared in the work of William James, Karl Jung, John Dewey and Sigmund Freud, all of whom emphasized the emotional and creative aspects of the child, highlighting love, indulgence of infant's needs, and the freedom of the individual. Freud (1856-1939), for example, recognized that all infants experienced emotional highs and lows and that even infants felt the need for love and possessed powerful desires. Freud recognized the importance of the body the oral, anal, and genital regions - as powerful organizers of the developing psyche. The vicissitudes of infant care led to a more or less repressed adult, one who accepted and enjoyed the body or felt repression about the body and its desires.

These romantic writers were relatively open about their own personal lives and used their experiences in part to inform their work. Watson, on the other hand, had a hidden and repressed romantic side. He was fired from his academic position at Johns Hopkins University in 1920 after it was found out that his research assistant, Rosalie Rayner, who was 21 years younger, was also his mistress. His wife, in the divorce proceedings, made public his letters to Rayner ("My total reactions are positive towards you.") to the newspapers in Baltimore and beyond. The psychological care of the infant and child, published 8 years later, when Watson had become an executive at an advertising agency, appears 
to be a willful act of revenge against academia, women, and probably infants as well (Hulbert, 2004).

Freud's daughter, Anna, following in the tradition of her father, taught parents to hold and cuddle their babies, to indulge their senses and respect their emotions. She counseled parents to be patient in order to allow their babies the time to manage their own desires in appropriate ways (Freud, 1965). On the other hand, Freud's ideas blamed parents who could not meet their children's needs. Parents were considered to be the main cause of neurosis and repression in their children. At the same time, during the 1930s and 1940s, there was an increased demand for infant education in nursery schools. This was meant to counter an overdependence on parents, prevent neurosis, and to give group training (Clarke-Stewart, 1998). It was also a response to the shortage of male workers during World War II and the need for women to join the workforce.

Following the war, the 1950s became a period of the redomestication of women in the United States. Mothers were expected to be the main infant care providers and fathers were meant to be the wage earners (Lamb, Sternberg, \& Ketterlinus, 1992). During this decade, there was revival of a more romantic view of relationships. This was the era of Abraham Maslow, Carl Rogers, Fritz Perls, and Willem Reich, each of whom created psychotherapies of caring, warmth, mutuality, responsibility, and affectivity. Reich in particular, a disciple of Freud, emphasized the importance of the body and its full expression of desires, senses, and pleasures, as a key to psychological health.

This is the period in which John Bowlby, mentioned earlier, began to publish his classic studies of mother-infant attachment. Bowlby believed in the importance of a close and affectionate mother-infant bond, a bond he believed to be primarily and exclusively with the infant's biological mother. He based his conclusions in part on observations of hunter-gatherer societies and in part on the evolution of humans during prehistory. A similar approach was taken by reformers of hospital childbirth procedures, who advocated a reduction in maternal anesthesia and a return to more natural and traditional approaches such as controlled breathing, upright postures, and home births. These reformers favored breast feeding over bottle feeding, and looked to Pleistocene practices in order to make childbirth a more satisfying and pleasurable experience for mother and infant. Few mothers and few hospitals of this era, however, adopted these practices.

The dialectic began to swing toward empiricism again in the 1960s and 1970s in the rapid growth of scientific approaches to psychology inspired in part by the Cold War, when Western leaders decided that the education and training of their citizens was the best way to combat the technological threats of advanced weapon systems. Research on infancy turned away from studies of emotion and focused more on infant learning and cognitive development. The Competent Infant (Stone, 1979) reflected a desire by scientists to discover early signs of intelligence in infants. Many parents placed their infants into highly structured programs to teach reading, word learning, music, and mathematics before the age of 3 years.

The rise of the women's liberation movement during this period conspired also to create an increased demand for infant day care and nursery schools. Betty Freidan's publication of Feminine Mystique in 1963, led to an increase in the numbers of women who sought individual fulfillment in their lives through employment and schooling. A 
final trend leading to increased demand for infant care during this period was the rise of single mothers who needed to be employed in order to support their children (Lamb et al., 1992).

The work of Jean Piaget from Switzerland and Lev Vygotsky of Russia began to inspire scientific understanding of infant cognitive development and how the infancy period served as a foundation for later intellectual functioning. Both Piaget (1952) and Vygotsky (1978) can also be read as primarily romantic thinkers since they viewed child development as a profoundly creative action, arising in the "natural" discourse between young children and their environments, including the cultural environment. Paradoxically, however, their work was read and applied - in infancy research and in early childhood education - primarily for its empiricist connotations; absorbed into the cultural search to make babies smarter.

This empiricist trend continued in the 1980s by an interest in helping and educating infants who were at risk for developmental difficulties, such as infants who were premature, handicapped, or victims of abuse. This focus on risk was associated with the empiricist idea that all humans can excel, given the right kind of childrearing (Clarke-Stewart, 1998). The same philosophy also brought the ideal of a "supermom" who could be employed, be a great mother, and wonderful and loving wife. The 1980s also saw an increase in the amount of time fathers spent with their babies.

The romantic view returns in the 1990s with a rise in studies of parent-child relationships, emotional development and attachment, and communication and language (Schneider, 1998) while the more empirical approaches to infant development continued to grow in such fields as cognitive neuroscience and behavior genetics. The trends of the 1970s and 1980s, which focused on babies growing up and getting smart as quickly as possible, are currently being replaced by ideas about slowing down and appreciating each phase of a baby's life. Research today has expanded to encompass diversity in parenting and culture: families at risk, substance abusers, handicapped infants, different ethnic groups, gay-lesbian families, fathers, preterm infants, and infantile autism. Meeting an infant's socioemotional needs is seen as important as cognitive and academic growth. There is also a focus on threats to safety such as accidents, abuse, crime, and the origins of psychopathology.

The recent return to romanticism has led to the growth of the holistic health and medicine movement with a focus on body awareness, yoga, massage, meditation, and the healing potential of relationships (Schneider, 1998). These ideas have their origins in ancient non-Western cultural beliefs, such as Chinese, Japanese, Indian, and Native American approaches. In this chapter on Western culture, there is no opportunity to review the history of beliefs about infants in these other cultures. A notable characteristic of these cultures is that, even in the twentieth century, the individual has not become salient in the cultural consciousness. These cultures, like ancient Western culture, were founded upon a mythical belief system in which humans were connected to all things. Their traditions focus on understanding and utilizing relationships between people, relationships between the various systems of mind and body, and between people and their social and physical environments. These cultures tend to be more romantic than empirical, accepting infant behavior in its "natural" form and rejecting early discipline and training of infants (cf. Kojima, 1986). 
There is also a recent trend in Western cultures toward using knowledge about infancy to contribute to the healing of older children and adults. Current psychoanalytic traditions advocate a therapist-client relationship that is modeled after what is believed to be the most healthy form of the mother-infant relationship: a balance between love and playfulness on the one hand and encouragement for independence and self-awareness on the other (Ehrenberg, 1992; Stern, 1985; Winnicott, 1971). There has been a partnership between therapists for adults and scientists who observe the mother-infant relationship. Somatic-awareness therapeutic approaches to adult healing are based on the recreation of observed patterns of infant learning through movement and touch. All of these methods are founded upon the view that there is something rejuvenating that occurs when adults reexperience their bodies and their interpersonal relationships in a way similar to being a baby.

Watsu, for example, is an aquatic somatic-awareness method that explicitly attempts to recreate an optimal infant experience. During a Watsu session, clients are moved freely in warm water, stretched gently, and cradled in the practitioner's arms. "By being moved so freely through the water, by being stretched and repeatedly returned to a fetal position, the adult has the opportunity to heal in himself whatever pain or loss he may still carry from that time" (Dull, 1995, p. 65).

In the Rosen Method, clients lie on a padded table while the practitioners' open hands make gentle contact with areas of the body that appear to hold muscular tension and restrict free breathing. Rosen practitioners believe that the body tells its own story shaped by early life experiences, many of them forgotten and unconscious. As a result of either ordinary or traumatic events, people shape themselves through muscular tension in whatever way that helps them to survive. Though the gentle touch of the Rosen Method, people deeply relax and breathe easier and begin to remember the experiences in which they learned to unconsciously contain their tension. Through that knowledge, the individual can regain fuller movement, ease, and a sense of well-being (Wooten, 1995).

Moshe Feldenkrais invented a system of body movement education that reawakens, develops, and organizes capacities for kinesthetic (sensori-motor) learning. Whereas children before the age of three learn movements by relying on their sensori-motor experience, older children and adults in technological cultures often behave according to social expectations, distancing themselves from their bodily feelings. As the Feldenkrais method involves the emulation of how young children learn, its therapeutic value hinges on releasing capacities for learning that had been left behind in childhood (Reese, 1985).

In summary, as in past centuries, the twentieth century continued the historical ebb and flow and romantic and empirical beliefs about babies. Individuality, human rights, and personal freedoms have become such a major component of Western cultures that it is easy to forget the "individual" was a cultural invention that became elaborated during the eighteenth, nineteenth, and twentieth centuries. Yet, from the perspective of the vast time scale of human existence on this planet, the individual is an aberrant form of consciousness. It was invented only a few seconds before midnight on the imaginary clock of human evolution that began at noon. It does not generalize to other cultures from which we have recently borrowed expertise in the healing arts: the Native American and the Chinese, for example. 


\section{Fogel}

The individual arose out of the historical and prehistorical romantic traditions respecting the value of the body and its senses. While the romantic view has lasted for as long as humans can remember, it is less clear - since the individual is a relative newcomer to human consciousness - whether the concept of the individual will survive and enhance human life or whether it will die out like many other cultural inventions. Whatever the ultimate significance of the individual for human growth and development, it is uniquely Western in its origin and application. The constitutional governments of most Western nations are founded on the value of the individual. Virtually every law enacted for and about infants and the family in the United States during the twentieth century, for example, is based on the notion of rights. The concept of the individual has spawned new forms of infancy beliefs such as the importance of independence training, a sense of entitlement that pervades early parent-infant discourses about the self, and a sense of fairness and rights that underlie Western conceptions of morality and ethics.

It is difficult to summarize the changes in infancy during the twentieth century. For further reference, I have written a book about what is known and understood about infants (Fogel, 2009). Partly, the difficulty of encapsulating the recent history of infancy is due to the complexity of change and partly to the historically unprecedented extent of documentary evidence. In addition to what has been mentioned, there are currently dozens of scientific journals devoted to prenatal and infant development, many magazines and books for parents, and thousands of Internet sites about infancy, ranging from scientific reports, to advocacy organizations, to infant care advice, and to family photos and videos. At least twice each week I can find a story in my local newspaper about pregnancy, childbirth, or infancy, about the life and death of babies in families, about technological and genetic innovations, or about legal and ethical issues such as harvesting stem cells from aborted fetuses. We are on the threshold of a future in which infancy may change in unknown ways.

\section{The Twenty-First Century and Beyond}

The specifics of the future cannot be foreseen but the general pattern, the empiricalromantic dialogue, will continue.

The empirical trends of the future will be related to finding new ways to control reproduction and fetal and infant development: the increasing application of engineering and biotechnology to the end of shaping the infant's body and mind to conform to a cultural ideal.

Speculation about empirical trends in the future comes from current genetic research. Scientists have already shown that replacing, selecting, or cloning genetic material is only part of the developmental story. The environment - its structure and timing - is also crucial to the developmental process. The new science of epigenetics is revealing how experiences become transformed into physiology by means of chemical and physical processes within the cell that regulate gene expression (e.g., Dolinoy, Weidman, \& Jirtle, 2007; Feinberg, 2007). We will come to know the precise environmental conditions under which certain genes will be expressed while others are suppressed. Part of the 
environmental control of the genes could come from within the organism. Scientists are already envisioning transplants of organic computers into the fetus or infant, transplants that will combine developmentally with inherited or altered genetic material to harness the body's power for releasing its own enzymes and transmitters that help regulate gene action for healthy development.

The romantic trends of the future will involve the continued discovery of the rejuvenating aspects of recreating infancy for adults and the revival and preservation of some of the patterns of the Pleistocene parent-infant relationship. The indulgent self-discovery that is the essence of infancy and early childhood today will be extended throughout the life course. The infancy period could thus be elongated in the form of continued playfulness, openness to new experiences, and a life-long commitment to getting up after falling down. All humans will accept and celebrate their differences as part of what is "natural" for the species in order to enhance our ability to adapt to unforeseen changes. Every baby will be an important addition to society, welcomed into a network of love and touch. Perhaps there will be an age in which no one will be unwanted, no one will be poor or hungry, and no one will lack services and supports. Every newborn will be entitled to love, security, shelter, nutrition, self-enhancement, and an extended family. In my romantic vision, we will indeed preserve our humanity. In fact, we will enhance what it means to have a human body that needs touch, love, and adventure. What we hunt and gather will be different but we will not cease wanting to participate in those endeavors.

Another future can be imagined: one that denigrates needs as frailties and that succeeds in eradicating them from the gene pool. Our bodies could be redesigned so that they will no longer be susceptible to heat and cold, hunger and pain. Sensation will become extinct. What would a baby in this future be like? Hard and withdrawn? Sucking power from a global energy grid with wide, vacant eyes? A disembodied mind? Since the romantic pleasures are our million-year inheritance and since they continue to be revived even after centuries of repression, I do not believe that humans could long endure this type of future. Enlightened romanticism requires training in how to use the body, how to develop one's skills at self-discovery and self-expression, how to remain connected with others and the world around us. Without romanticism, empiricism becomes harsh and intolerable. Endurance and indulgence, self and other, separateness and connection, mind and body: these are birthrights.

\section{References}

Abram, D. (1996). The spell of the sensuous. New York: Vintage Books.

Barr, R. G. (1990). The early crying paradox: A modest proposal. Human Nature, 1, 355-389.

Bowlby, J. (1969). Attachment and loss: Vol. 1. Attachment. New York: Basic Books.

Bronfenbrenner, U. (1979). The ecology of human development: Experiments by nature and design. Cambridge, MA: Harvard University Press.

Clarke-Stewart, K. A. (1998). Historical shifts and underlying themes in ideas and rearing young children in the United States: Where have we been? Where are we going? Early Development and Parenting, 7, 101-117.

Conrad, R. (1998). Darwin's baby and baby's Darwin: Mutual recognition in observational research. Human Development, 41(1), 47-64. 


\section{Fogel}

Conrad, R. (2004). "[A]s if she defied the world in her joyousness": Rereading Darwin on emotion and emotional development. Human Development, 47, 40-65.

Dolinoy, D. C., Weidman, J. R., \& Jirtle, R. L. (2007). Epigenetic gene regulation: Linking early developmental environment to adult disease. Reprod Toxicol, 23(3), 297-307.

Donald, M. (1991). Origins of the modern mind: Three stages in the evolution of culture and cognition. Cambridge, MA: Harvard University Press.

Dull, H. (1995). Watsu: Freeing the body in water (2nd ed.). Harbin, CA: Harbin Springs Publishing.

Dupont, F. (1989). Daily life in ancient Rome. (C. Woodall, Trans.). Oxford: Blackwell.

Ehrenberg, D. (1992). The intimate edge: Extending the reach of psychoanalytic interaction. New York: W.W. Norton \& Company.

Eisler, R. (1987). The chalice and the blade: Our history, our future. San Francisco: Harper Collins.

Feinberg, A. P. (2007). Phenotypic plasticity and the epigenetics of human disease. Nature, 447(7143), 433-440.

Fogel, A. (2009). Infancy: Infant, family and society (5th ed.). New York: Sloan Publishing.

French, V. (2001). History of parenting: The ancient Mediterranean world. In M. Bornstein (Ed.), Handbook of Parenting (Vol. 3, pp. 345-376). Mahwah, NJ: Erlbaum.

Freud, A. (1965). Normality and pathology in childhood. New York: International Universities Press.

Frymer-Kensky, T. (1995). Motherprayer: The pregnant woman's spiritual companion. New York: Riverhead Books.

Gaskell, E. (1996). Elizabeth Gaskell's diary. In J. A. Chapple \& A. Wilson (Eds.), Private voices: The diaries of Elizabeth Gaskell and Sophia Holland (pp. 11-71). New York: St. Martin's Press.

Gelis, J. (1989). The child: From anonymity to individuality. In P. Aries \& G. Duby (Eds.), $A$ history of private life (pp. 309-325). Cambridge, MA: Harvard University Press.

Gies, F., \& Gies, J. (1987). Marriage and the family in the middle ages. New York: Harper and Row.

Greenleaf, P. (1978). Children throughout the ages: A history of childhood. New York: Barnes \& Noble.

Hanawalt, B. A. (1993). Growing up in medieval London: The experience of childhood in history. New York: Oxford University Press.

Hareven, T. K. (1985). Historical changes in the family and the life course: Implications for child development. Monographs of the Society for Research in Child Development, 50 (Serial No. 211), $8-23$.

Hewlett, B. S., Lamb, M. E., Shannon, D., Leyendecker, B., \& Scholmerich, A. (1998). Culture and early infancy among central African foragers and farmers. Developmental Psychology, 34(4), 653-661.

Hrdy, S. B. (1999). Mother nature: A history of mothers, infants, and natural selection. New York: Pantheon.

Huizinga, J. (1954). The waning of the middle ages. New York: Anchor Books.

Hulbert, A. (2004). Raising America: Experts, parents, and a century of advice about children. New York: Random House.

Johnson, D.H. (1992). Body: Recovering our sensual wisdom. In D. Johnson \& I. Grand (Eds.), The body in psychotherapy: Inquiries into somatic psychology (pp. 1-16). Berkeley, CA: North Atlantic.

Kojima, H. (1986). The history of child development in Japan. In H. Azuma \& H. Stevenson (Eds.), Child development and education in Japan (pp. 39-54). New York: Academic Press.

Konner, M. (1982). The tangled wing: Biological constraints on the human spirit. New York: Holt, Rinehart, \& Winston.

Koops, W. (1996). Historical developmental psychology: The sample case of paintings. International Journal of Behavioral Development, 19(2), 393-413. 
Lamb, M. E., Sternberg, K. J., \& Ketterlinus, R. D. (1992). Child care in the United States: The modern era. In M.E. Lamb, K. J. Sternberg, C. Hwang, \& A. Broberg (Eds.), Childcare in context: Cross-cultural perspectives (pp. 207-222). Hillsdale, NJ: Erlbaum.

Le Goff, J. (1987). The medieval world. (L. G. Cochrane, Trans.). London: Collins and Brown Ltd.

Mead, M., \& Newton, N. (1967). Cultural patterning of perinatal behavior. In S. Richardson \& A. Guttmacher (Eds.), Childbearing: Its social and psychological aspects (pp. 142-244). Baltimore, MD: Williams \& Wilkins.

Piaget, J. (1952). The origins of intelligence in children. New York: International Universities Press.

Pomeroy, S. B. (1999). Plutarch's advice to the bride and groom and a consolation to his wife. New York: Oxford University Press.

Reese, M. (1985). Moshe Feldenkrais's work with movement: A parallel approach to Milton Erickson's hypnotherapy. In J. K. Zeig (Ed.), Ericksonian psychotherapy: Vol. I.: Structures (pp. 410-427). New York: Brunner/Mazel.

Saint Augustine (1991). Confessions. (Henry Chadwick, Trans.). New York: Oxford University Press.

Schneider, K. J. (1998). Toward a science of the heart: Romanticism and the revival of psychology. American Psychologist, 53(3), 277-289.

Screech, M. A. (Ed. and Trans.). (1991). Michel De Montaigne: The complete essays. Harmondsworth, England: Penguin Books.

Shepard, P. (1998). Coming home to Pleistocene. Covelo, CA: Island Press.

Shostak, M. (1983). Nisa: The life and words of a !Kung woman. New York: Vintage Books.

Sorenson, E. R. (1979). Early tactile communication and the patterning of human organization: A New Guinea case study. In M. Bullowa (Ed.), Before speech (pp. 289-305). New York: Cambridge University Press.

Stern, D. N. (1985). The interpersonal world of the infant. A view from psychoanalysis and development psychology. New York: Basic Books.

Stone, L. (1979). The family, sex and marriage in England 1500-1800. New York: Harper and Row.

Vygotsky, L. S. (1978). Mind in society. Cambridge, MA: Harvard University Press.

Wallace, D. B., Franklin, M. B., \& Keegan, R. T. (1994). The observing eye: A century of baby diaries. Human Development, 37, 1-29.

Wenke, R.J. (1990). Patterns in prehistory: Humankind's first three million years. New York: Oxford University Press.

Whiten, A., \& Milner, P. (1986). The educational experiences of Nigerian infants. In H. V. Curran (Ed.), Nigerian children: Developmental perspectives (pp. 34-73). London: Routledge \& Kegan Paul.

Whiting, B. (1974). Folk wisdom and child-rearing. Merrill-Palmer Quarterly, 20, 9-19.

Williams, O. (1952). Immortal poems of the English language. New York: Washington Square Press. Winnicott, D.W. (1971). Playing and reality. New York: Basic Books.

Wooten, S. (1995). Touching the body reaching the soul: How touch influences the nature of human beings. Santa Fe, NM: Rosen Method Center Southwest. 
